\author{
Monika Wieczorek-Kosmala \\ Joanna Błach \\ Anna Doś \\ Maria Gorczyńska \\ Katedra Finansów \\ Uniwersytet Ekonomiczny w Katowicach
}

\title{
Derywaty ubezpieczeniowe w zarządzaniu ryzykiem - perspektywa przedsiębiorstwa*
}

\section{Streszczenie}

Derywaty ubezpieczeniowe obejmują grupę instrumentów pośrednich pozwalających na dokonywanie transferu ryzyka ubezpieczeniowego na rynek kapitałowy. Celem artykułu jest uzasadnienie tezy, że derywaty te mogą w przyszłości stać się ważnym instrumentem zarządzania ryzykiem w przedsiębiorstwach, choć obecnie skala ograniczeń ich zastosowania jest istotna. Rynek derywatów ubezpieczeniowych jest obecnie zdominowany przez reasekuratorów i ubezpieczycieli, postępujące jednak procesy konwergencji rynku finansowego i ubezpieczeniowego mogą prowadzić do powstania nowych rozwiązań bądź stosowania rozwiązań istniejących na nowych polach. W artykule przybliżono istotę i pochodzenie derywatów ubezpieczeniowych, dokonano także przeglądu ich podstawowych rodzajów. Zastosowano głównie metodę analizy literatury oraz dokumentów pisanych w postaci raportów tematycznych czołowych instytucji międzynarodowych zajmujących się praktyką derywatów ubezpieczeniowych.

Słowa kluczowe: ryzyko, zarządzanie ryzykiem, derywaty, derywaty ubezpieczeniowe, przedsiębiorstwa.

* Projekt, w ramach którego powstało niniejsze opracowanie, został sfinansowany ze środków Narodowego Centrum Nauki przyznanych na podstawie decyzji numer DEC-2011/01/D/ $\mathrm{HSH} / 04003$. 


\section{Wprowadzenie}

Ważnym obszarem rozwoju współczesnego systemu finansowego jest postępująca konwergencja rynku finansowego i rynku ubezpieczeń. Przyjmuje ona wiele form, a jedną z nich jest możliwość dokonywania transferu ryzyka ubezpieczeniowego na rynek kapitałowy. Uważa się, że głównym impulsem rozwoju tej konwergencji były rozmiary szkód związanych z ryzykiem katastroficznym oraz zmienność cyklu ubezpieczeniowego [Banks 2004, s. 59; Cummins i Weiss 2009, s. 494].

Dla zarządzania ryzykiem zjawiska konwergencji rynku finansowego i rynku ubezpieczeń mają istotne znaczenie, gdyż prowadzą do powstania m.in. nowych mechanizmów i instrumentów stwarzających możliwość budowy lepszych i efektywniejszych rozwiązań w zakresie zarządzania ryzykiem. W niniejszym artykule skupiono się na jednym z takich rozwiązań - derywatach ubezpieczeniowych, obejmujących grupę instrumentów pośrednich pozwalających na dokonywanie transferu ryzyka ubezpieczeniowego na rynek kapitałowy. Przesłanką powstania tych derywatów była potrzeba lepszego, alternatywnego zarządzania ryzykiem przez reasekuratorów i ubezpieczycieli. Podmioty te do dziś stanowią trzon tego rynku. Niektóre z nich znajdują jednak zastosowanie w zarządzaniu ryzykiem podmiotów sektora niefinansowego. Za główny cel niniejszego artykułu przyjęto więc uzasadnienie tezy, że derywaty ubezpieczeniowe mogą w przyszłości stać się ważnym instrumentem zarządzania ryzykiem w przedsiębiorstwach, choć obecnie skala ograniczeń ich zastosowania jest istotna. Refleksja taka wypływa ze świadomości postępującego procesu konwergencji rynku finansowego i ubezpieczeniowego, mogącej prowadzić zarówno do powstania nowych instrumentów finansowych, jak i stosowania instrumentów już powstałych na nowych polach. Na poparcie postawionej tezy w artykule przybliżono istotę i rodowód derywatów ubezpieczeniowych, a także dokonano przeglądu ich podstawowych rodzajów. Derywaty ubezpieczeniowe jako instrument zarządzania ryzykiem rozpatrywane są tu wyłącznie w funkcji hedgingowej, co odpowiada ich zastosowaniu w celu niwelowania ujemnych skutków ryzyka.

Artykuł opiera się na analizie treści dostępnych źródeł literatury poruszającej problem derywatów ubezpieczeniowych, ale również szerzej traktującej problem zjawisk będących pochodną konwergencji rynku finansowego i rynku ubezpieczeń, takich jak np. sekurytyzacja ryzyka ubezpieczeniowego. Zastosowano również metodę analizy dokumentów pisanych, w postaci raportów tematycznych najważniejszych instytucji międzynarodowych zajmujących się praktyką sekurytyzacji ryzyka ubezpieczeniowego i ILS (insurance-linked securities). W pierwszej części odniesiono się ogólnie do problemu zastosowania derywatów w zarządzaniu ryzykiem, w drugiej przedstawiono istotę i wybrane, główne rodzaje derywatów 
ubezpieczeniowych, a w trzeciej podjęto dyskusję nad możliwymi obszarami i kierunkami ich zastosowania w przedsiębiorstwach.

\section{Znaczenie derywatów w zarządzaniu ryzykiem}

Derywaty jako instrumenty zarządzania ryzykiem wykorzystywano już ponad 2000 lat temu w starożytnej Grecji. Pierwotnie kontrakty te służyły ograniczaniu ryzyka niekorzystnej zmiany cen towarów (surowców, płodów rolnych). Wraz z rozwojem systemu finansowego oraz powstawaniem zorganizowanych rynków giełdowych pojawiały się nowe kategorie derywatów opiewających na instrumenty finansowe: akcje, obligacje, waluty, indeksy giełdowe, stopy procentowe czy umowy kredytowe ${ }^{1}$. Gwałtowny rozwój rynku derywatów rozpoczął się w latach 70. XX w. i dzięki osiągnięciom inżynierii finansowej trwa do chwili obecnej. Ewolucja derywatów postępuje - regularnie na rynku pojawiają się innowacje opiewające na nowe klasy aktywów bazowych prostych i złożonych.

Derywaty tworzą szeroką klasę instrumentów finansowych, które mogą być klasyfikowane na podstawie różnych kryteriów. W zależności od charakteru umowy określającej prawa i obowiązki stron transakcji derywaty można podzielić na bezwarunkowe oraz warunkowe. Derywaty bezwarunkowe, obejmujące transakcje swapowe, forward i futures, zawierają obowiązek realizacji postanowień umowy w określonym terminie w przyszłości na z góry określonych zasadach. Kontrakty tego typu noszą również miano transakcji symetrycznych, ponieważ potencjalny zysk jednej ze stron transakcji będzie zawsze równy maksymalnej stracie poniesionej przez drugą ze stron (kontrakty o symetrycznym ryzyku). Warunkowe instrumenty pochodne - opcje i warranty - dają nabywcy prawo, a nie obowiązek, wykonania umowy; tylko wystawca kontraktu ma obowiązek jego realizacji na wniosek nabywcy. Jednocześnie potencjalne zyski i straty strony kontraktu rozkładają się niesymetrycznie (kontrakty o asymetrycznym ryzyku).

Pod względem miejsca obrotu derywaty dzieli się na notowane na giełdach (exchange-traded derivatives - ETD) oraz na rynku pozagiełdowym (over-the-counter - OTC). Zorganizowane rynki derywatów pełnią dwojaką funkcję: zwiększają przejrzystość zawieranych transakcji (przez dostępność informacji na temat ich skali i wartości) oraz ograniczają ryzyko niedotrzymania warunków transakcji (poprzez pośrednictwo izby rozliczeniowej i codzienne rozliczanie pozycji).

Zainteresowanie inwestorów derywatami wynika ze specyficznej konstrukcji tych instrumentów, pozwalającej na różnorodne zastosowanie ${ }^{2}$. Prócz transakcji

\footnotetext{
${ }^{1}$ Szerzej na temat historii derywatów zob. m.in. [Swan 2000].

${ }^{2}$ Szerzej na temat konstrukcji derywatów zob. m.in. [Hull 2011, Durbin 2011].
} 
spekulacyjnych i arbitrażowych derywaty dają przede wszystkim możliwość hedgingu, czyli zabezpieczenia ryzyka poprzez jego transfer na partnera transakcji. Zastosowanie derywatów w zarządzaniu ryzykiem jest szerokie - umożliwiają neutralizację zarówno pojedynczego ryzyka, jak i całego portfela ekspozycji z zastosowaniem złożonych struktur. W rezultacie hedging daje szansę poszerzenia przestrzeni dla angażowania się w dodatkową działalność obarczoną ryzykiem, która ma z założenia przynieść określone korzyści [Banks 2004, s. 149].

\section{Derywaty ubezpieczeniowe}

Derywaty ubezpieczeniowe należą do grupy instrumentów, które pozwalają dokonać transferu ryzyka ubezpieczeniowego na rynek kapitałowy. Ewolucja i zastosowanie tych derywatów jest ściśle związane z mechanizmem tzw. sekurytyzacji ryzyka ubezpieczeniowego. Sekurytyzacja jako technika finansowa rozwinęła się w latach 70. XX w. Polega ona na łączeniu jednorodnych, niepłynnych aktywów o przewidywalnych przepływach pieniężnych, które następnie stają się zabezpieczeniem dla płynnych papierów wartościowych (zwykle dłużnych), będących przedmiotem obrotu na rynkach finansowych. Przyszłe płatności z aktywów stanowią podstawę do późniejszej spłaty wyemitowanych papierów wartościowych (asset-backed securities - ABS). W ten sposób inicjator sekurytyzacji może szybciej i łatwiej refinansować wybrane pozycje aktywów, zwiększając płynność i poprawiając strukturę bilansu. Aktywa będące przedmiotem sekurytyzacji mogą być bardzo różnorodne, w związku z tym sekurytyzacja może być stosowana przez różne podmioty, głównie finansowe (banki, instytucje ubezpieczeniowe itp.), ale także przedsiębiorstwa niefinansowe [Kreczmańska-Gigol 2009].

W dziedzinie ubezpieczeń zjawisko sekurytyzacji jest wciąż uważane za relatywnie nowe. Początki tej sekurytyzacji obserwowano w latach 90. XX w. Miały one związek z problemami, jakie na globalnym rynku ubezpieczeń i reasekuracji pojawiły się po serii zjawisk katastroficznych. Po huraganie Andrew w 1992 r. odnotowano najwyższe w historii szkody w sektorze ubezpieczeń majątkowych. Straty ubezpieczycieli pogłębiły wkrótce szkody wywołane serią huraganów w 2005 r. (huragany KRW - Katrina, Rita i Wilma) [Cummins i Weiss 2009, s. 494]. Po tych wydarzeniach obserwowano na rynku ubezpieczeń występowanie fazy rynku „twardego”, która wiąże się z ograniczeniem podaży ubezpieczeń i wzrostem ceny ochrony.

Sekurytyzacja ryzyka ubezpieczeniowego rozwijana jest głównie na potrzeby sektora ubezpieczeń, tworząc alternatywę dla reasekuracji. Z tego względu inicjatorami transakcji sekurytyzacyjnych oraz ich uczestnikami są przede wszystkim reasekuratorzy i ubezpieczyciele. W sensie produktowym sekurytyzacja ryzyka 
ubezpieczeniowego skutkuje pojawieniem się na rynku finansowym ILS. Określeniem tym obejmuje się grupę instrumentów finansowych, które pozwalają kierować (cedować) ryzyko ubezpieczeniowe na rynek kapitałowy [Helfenstein i Holzheu 2006, s. 4; Weber 2011]. Instrumenty te finalnie nabywane są przez różne grupy inwestorów, którzy mogą kierować się motywem spekulacyjnym bądź hedgingowym.

W większości opracowań derywaty ubezpieczeniowe uznawane są za jedną $\mathrm{z}$ form ILS ${ }^{3}$ i bywają określanie mianem event-linked derivatives. Są to kontrakty finansowe, których wartość uzależniona jest od wystąpienia określonego zdarzenia, przy czym występowanie danego zdarzenia często pośrednio wpływa na realizację kontraktu. Wynika to z faktu, że konstrukcja większości derywatów ubezpieczeniowych opiera się na zastosowaniu tzw. indeksów parametrycznych jako podstawy rozliczenia kontraktu. Oznacza to, że płatności z derywatów ubezpieczeniowych zależne są od zmian wartości indeksu parametrycznego. Wartości tych indeksów mogą opierać się na różnych zagrożeniach (triggers). Do najbardziej znanych należą: indeks PCS Industry Loss Index (Property Claims Services), będący rodzajem indeksu branżowego (industry index), którego wartość jest ustalana na podstawie szkód wybranych, reprezentatywnych podmiotów, dalej czysty indeks parametryczny (pure parametric index), którego wartość ustala się na podstawie realnych szkód z tytułu określonego ryzyka (np. magnituda trzęsienia ziemi), czy indeks modelowany (modelled index), którego wartość oblicza się z zastosowaniem określonych modeli szkód [Frey, Kirova i Schmidt 2009, s. 5; Helfenstein i Holzheu 2006, s. 6].

Derywaty ubezpieczeniowe mogą występować w formie opcji, swapów i kontraktów futures. Trudno przedstawić jednoznacznie uporządkowaną klasyfikację tych instrumentów. Dostępne źródła literaturowe niejednokrotnie koncentrują się na przedstawieniu studiów przypadku, stąd spotyka się wiele różnych ujęć klasyfikacyjnych, zależnie od tego, jaki problem był w centrum uwagi badacza ${ }^{4}$. Przegląd tych źródeł skłania do wniosku, że dogodną podstawą klasyfikacji derywatów ubezpieczeniowych jest przede wszystkim rodzaj ryzyka (zdarzenia), którego dotyczą, oraz rodzaj rynku, na którym transakcje te są zawierane (rys. 1).

${ }^{3}$ Derywaty ubezpieczeniowe traktowane są jako rodzaj ILS w opracowaniach Swiss Re [Frey, Kirova i Schmidt 2009] oraz w pracy [Cummins i Weiss 2009, s. 515]. Inne ujęcie proponuje E. Banks [2004, s. 50], klasyfikując derywaty ubezpieczeniowe jako odrębną obok ILS grupę instrumentów alternatywnego transferu ryzyka.

${ }^{4}$ W piśmiennictwie polskojęzycznym do problemu odniosła się A. Małek [2011, s. 153-174], która analizując derywaty ubezpieczeniowe w kontekście alternatywy wobec reasekuracji tradycyjnej, podzieliła je według rodzaju instrumentów. W opracowaniach anglojęzycznych dominuje podział derywatów ubezpieczeniowych na katastroficzne i pozostałe oraz na będące przedmiotem transakcji giełdowych bądź OTC [Banks 2004, s. 156-167; Frey, Kirova i Schmidt 2009, s. 15; Weber 2011, s. 80-84]. 


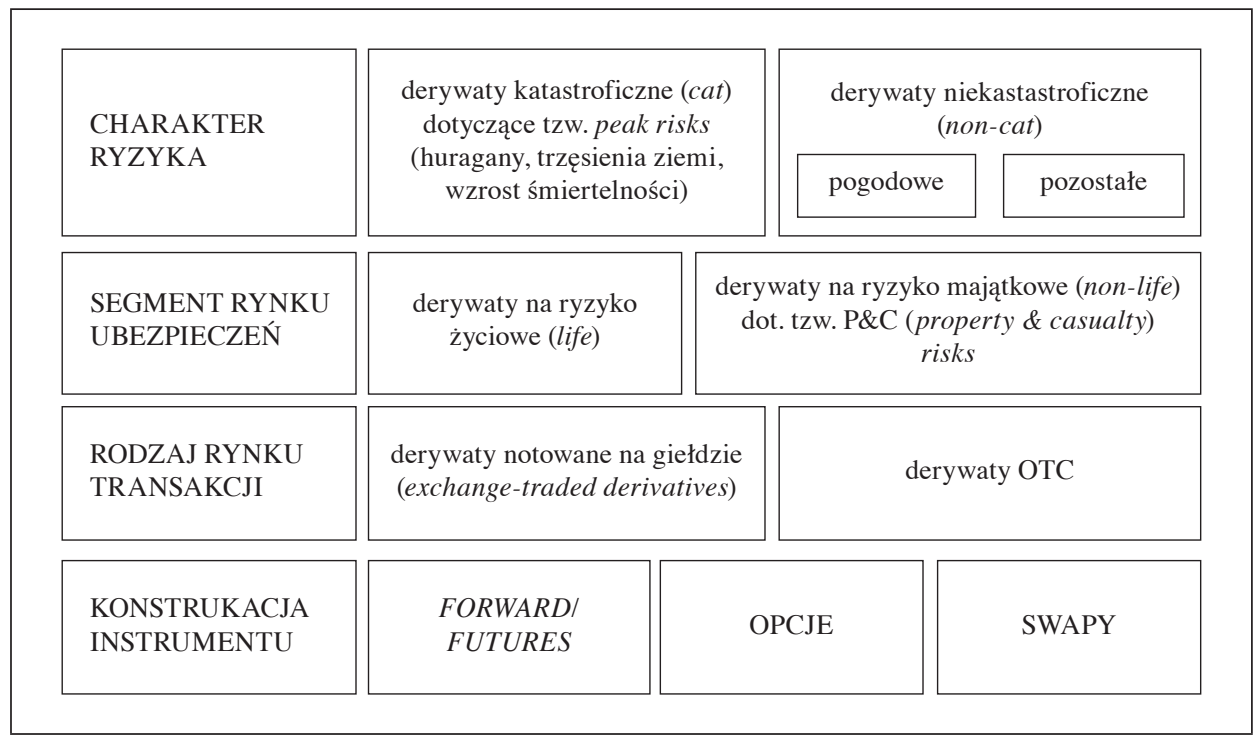

Rys. 1. Klasyfikacja derywatów ubezpieczeniowych

Źródło: opracowanie własne.

Na rys. 2 przedstawiono charakterystykę najważniejszych derywatów ubezpieczeniowych dostępnych na rynkach światowych. Derywaty katastroficzne są przedmiotem transakcji zarówno na rynkach OTC, jak i giełdowych, przy czym uważa się, że rozwój tych instrumentów na rynkach giełdowych jest raczej powolny [Frey, Kirova i Schmidt 2009, s. 18; Bouriaux i Tomas 2014]. Do obrotu giełdowego derywaty ubezpieczeniowe wprowadzono w 1992 r. na CBOT (Chicago Board of Trade), ale zostały w $2000 \mathrm{r}$. wycofane $\mathrm{z}$ obrotu z uwagi na niskie zainteresowanie nimi [Cummins i Weiss 2009, s. 516]. W późniejszym okresie tego typu derywaty wprowadzono na trzech rynkach giełdowych: CME (Chicago Merchantile Exchange, kontrakty futures i opcje), Chicago Climate Futures Exchange i Eurex (kontrakty futures, tzw. ELFs - event-linked futures). Kontrakty te dotyczą ryzyka huraganowego na terenie USA [Frey, Kirova i Schmidt 2009, s. 18-19; Cummins i Weiss 2009, s. 518-519; Bouriaux i Tomas 2014, s. 38-40].

W zakresie ryzyka katastroficznego przedmiotem transakcji na rynku OTC są głównie swapy katastroficzne. Uznawane są one za bardzo elastyczne instrumenty, pozwalające na ochronę przed ryzykiem katastroficznym rynku ubezpieczeń majątkowych (huragany, trzęsienia ziemi, tajfuny, akty terroru) oraz życiowych (długowieczność i śmiertelność). W transakcjach tego typu podmiot cedujący ryzyko godzi się na serie płatności (stałych) na rzecz partnera transakcji, w zamian za zmienne płatności zależne od wystąpienia określonego zdarzenia [Cummins i Weiss 2009, s. 520; Banks 2004, s. 162-164; Bouriaux i Mac Minn 2009, s. 31]. 


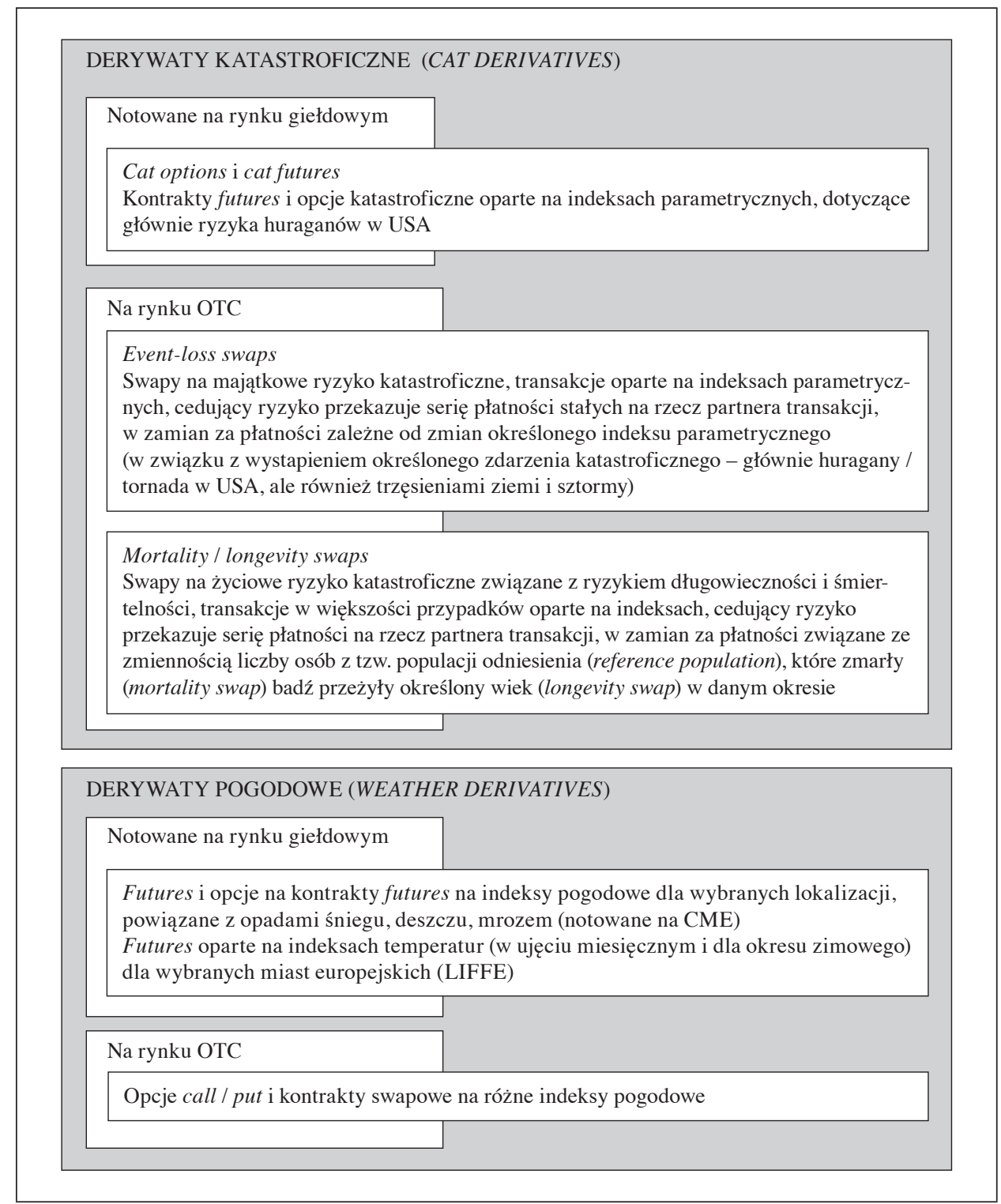

\section{Rys. 2. Charakterystyka derywatów ubezpieczeniowych}

Źródło: opracowanie własne na podstawie [Banks 2004, Bouriaux i MacMinn 2009, Brockett, Wang i Yang 2005, Frey, Kirova i Schmidt 2009].

Derywaty pogodowe (weather derivatives) to kontrakty dotyczące ryzyka pogodowego, tj. temperatury, wilgoci, wiatru itd. Ich zastosowanie pozwala na 
zarządzanie ryzykiem związanym z ekspozycją na straty z tytułu niekorzystnych zjawisk pogodowych. Derywaty pogodowe należą do stosunkowo dobrze rozpoznanych derywatów ubezpieczeniowych. Znajdują one szerokie zastosowanie $\mathrm{w}$ sektorze niefinansowym - korzystają z nich koncerny energetyczne w celu redukowania strat finansowych w sytuacji zmiany popytu na energię z powodu nadspodziewanie wysokiej bądź niskiej temperatury. Kontraktami tymi interesują się również podmioty z sektora agrobiznesu, transportu, budownictwa oraz branży turystycznej [Convergence of... 2008, s. 13; Binkowski 2008, Bank i Wiesner 2010]. W większości derywaty pogodowe są kontraktami rynku OTC ${ }^{5}$. W obrocie giełdowym oferowane są na rynku CME (Chicago Mercantile Exchange) ${ }^{6}$.

\section{Zastosowanie derywatów ubezpieczeniowych w zarządzaniu ryzykiem przedsiębiorstw}

Rozważając uzasadnione możliwości zastosowania derywatów ubezpieczeniowych w zarządzaniu ryzykiem przedsiębiorstw, warto zauważyć na wstępie, że derywaty ubezpieczeniowe są uznawane za rozwiązania nietypowe, stanowiące jedną z gałęzi tzw. ART (alternative risk transfer). Rozwiązania ART są powszechnie uznawane za odpowiednie dla podmiotów, które poszukują dopasowanych i elastycznych rozwiązań, wspierających efektywność programu zarządzania ryzykiem. Przedsiębiorstwa jako użytkownicy nietypowych rozwiązań migrują na rynek ART, stając się aktywnymi uczestnikami tych transakcji, również tych z zastosowaniem derywatów ubezpieczeniowych.

Dominuje pogląd, że rynek ART jest atrakcyjny przede wszystkim dla wielkich, międzynarodowych korporacji, które zarządzając ryzykiem, koncentrują się głównie na jego retencji, poszukując jednocześnie dopasowanej ochrony dla ryzyka unikatowego (często nieubezpieczalnych na tradycyjnym rynku ubezpieczeń). Niska aktywność małych firm, a co za tym idzie - ich szczątkowy udział w rynku ART, jest przede wszystkim następstwem postaw pośredników finansowych (szczególnie brokerów), którzy z reguły projektują i proponują nietypowe rozwiązania wyłącznie klientom korporacyjnym [Banks 2004, s. 56].

Biorąc pod uwagę przynależność derywatów ubezpieczeniowych do grupy metod alternatywnego transferu ryzyka, należy zauważyć, że w przedsiębior-

${ }^{5}$ Według raportu Weather Risk Management Association na temat rozwoju rynku derywatów pogodowych w latach 2010-2011 rynek OTC wzrósł o 30\%, osiągając wartość 2,4 mld USD, podczas gdy cały światowy rynek tych instrumentów wzrósł o 20\%, osiągając wartość 11,8 mld USD [Weather... 2011].

6 Zob. również [Frey, Kirova i Schmidt 2009, s. 20; Banks 2004, s. 157-162] oraz przykłady zastosowania [Brockett, Wang i Yang 2005, s. 128-131]. 
stwach (jako stronach transakcji) derywaty te mogą pełnić jednocześnie funkcję substytucyjną i komplementarną wobec innych możliwych metod zarządzania ryzykiem. Derywaty ubezpieczeniowe mogą stać się substytutem dla ubezpieczeń tradycyjnych, jeżeli dotyczą ryzyka możliwego do ubezpieczenia w sposób tradycyjny. Należy je natomiast traktować jako komplementarne wobec tradycyjnych ubezpieczeń wówczas, gdy stwarzają możliwość zabezpieczenia ryzyka, które nie jest przedmiotem ochrony w ramach ubezpieczeń tradycyjnych. Na rys. 3 przedstawiono główne cechy, pod względem których porównano derywaty ubezpieczeniowe i ubezpieczenia tradycyjne.

\begin{tabular}{|c|c|c|}
\hline & $\begin{array}{c}\text { DERYWATY } \\
\text { UBEZPIECZENIOWE }\end{array}$ & UBEZPIECZENIA \\
\hline $\begin{array}{l}\text { Warunki } \\
\text { uzyskania } \\
\text { wypłaty }\end{array}$ & $\begin{array}{l}\text { wypłata bez konieczności } \\
\text { udowodnienia straty, } \\
\text { wyłącznie na podstawie } \\
\text { notowania (wartości) } \\
\text { wybranego indeksu będącego } \\
\text { punktem odniesienia }\end{array}$ & $\begin{array}{l}\text { konieczność udowodnienia } \\
\text { poniesionej straty na skutek } \\
\text { wystąpienia zdarzenia } \\
\text { ubezpieczeniowego }\end{array}$ \\
\hline $\begin{array}{l}\text { Motywy } \\
\text { zawierania } \\
\text { kontraktu }\end{array}$ & $\begin{array}{l}\text { nie jest wymagane } \\
\text { przedstawienie (a tym samym } \\
\text { upublicznianie) żadnych } \\
\text { informacji }\end{array}$ & $\begin{array}{l}\text { konieczność przedstawienia } \\
\text { informacji wymaganych } \\
\text { przez ubezpieczyciela }\end{array}$ \\
\hline Dostępność & $\begin{array}{l}\text { niska, } \\
\text { istotne ograniczenia podaży } \\
\text { rynku, również ze strony } \\
\text { pośredników }\end{array}$ & wysoka \\
\hline $\begin{array}{l}\text { Koszty } \\
\text { transakcyjne }\end{array}$ & $\begin{array}{l}\text { relatywnie wysokie i trudne } \\
\text { do ustalenia }\end{array}$ & $\begin{array}{l}\text { relatywnie niskie i łatwe } \\
\text { do ustalenia }\end{array}$ \\
\hline $\begin{array}{l}\text { Stopień } \\
\text { komplikacji } \\
\text { rozwiązania }\end{array}$ & $\begin{array}{l}\text { wysoki, wymaga } \\
\text { specjalistycznej wiedzy } \\
\text { o funkcjonowaniu i wycenie } \\
\text { kontraktu }\end{array}$ & $\begin{array}{l}\text { niski, wiedza o podstawach } \\
\text { funkcjonowania ubezpieczeń } \\
\text { jest relatywnie powszechna }\end{array}$ \\
\hline $\begin{array}{l}\text { Regulacje } \\
\text { prawne }\end{array}$ & $\begin{array}{l}\text { niedookreślone zasady } \\
\text { rozliczania księgowego } \\
\text { i podatkowego }\end{array}$ & $\begin{array}{l}\text { jasno określone zasady } \\
\text { rozliczania księgowego } \\
\text { i podatkowego }\end{array}$ \\
\hline
\end{tabular}

Rys. 3. Porównanie derywatów ubezpieczeniowych i ubezpieczenia tradycyjnego Źródło: opracowanie własne. 
Wśród istotnych źródeł przewagi derywatów ubezpieczeniowych nad ubezpieczeniami tradycyjnymi wymienia się ujawnianie informacji oraz warunki uzyskania wypłaty świadczenia kompensującego poniesione straty. W ubezpieczeniach tradycyjnych przy zawieraniu ubezpieczenia wymagane jest przekazanie informacji pozwalających określić skalę ryzyka przyjmowanego do ubezpieczenia (i na tej podstawie ustalić jego koszt). W razie realizacji ryzyka konieczne jest natomiast zgłoszenie szkody i odpowiednie jej udokumentowanie. Przy zastosowaniu derywatów ubezpieczeniowych przekazywanie powyższych informacji nie jest konieczne, dzięki zastosowaniu mechanizmu wypłat opartego na indeksach parametrycznych [Bank i Weisner 2010, s. 548-585; Zailer 2004, s. 107-113] ${ }^{7}$.

Na rys. 3 zwrócono uwagę również na czynniki ograniczające zastosowanie derywatów ubezpieczeniowych w przedsiębiorstwach [Bank i Wiesner 2010, s. 589-597]. Czynniki te pozostają w znacznym stopniu współzależne. Po pierwsze istnieją poważne ograniczenia strony podażowej derywatów ubezpieczeniowych, przekładające się na ich relatywnie niską dostępność. Derywaty będące przedmiotem transakcji na rynkach giełdowych są teoretycznie dostępne dla wszelkich zainteresowanych podmiotów (a więc również i przedsiębiorstw). Istniejące rozwiązania są jednak często niedopasowane do ich potrzeb, a pośrednicy nie są zainteresowani przygotowaniem i zmodyfikowaniem odpowiednich rozwiązań, szczególnie dla podmiotów mniejszych. Za istotny czynnik ograniczający ich dostępność uznać należy również brak działań edukacyjnych i promocyjnych, na przykład ze strony pośredników finansowych.

Kolejną barierą ograniczającą zastosowanie derywatów są wysokie koszty transakcyjne w porównaniu z ubezpieczeniami tradycyjnymi. Na wysokość tych kosztów wpływają przede wszystkim koszty indywidualnego negocjowania kontraktu, prowizji dla pośredników czy dostępu do informacji o odpowiednich indeksach parametrycznych. Co więcej, przedsiębiorstwu niejednokrotnie trudno jest określić wysokość tych kosztów, głównie ze względu na niski poziom znajomości zasad funkcjonowania derywatów ubezpieczeniowych.

Trzecim istotnym czynnikiem ograniczającym możliwość zastosowania derywatów ubezpieczeniowych w przedsiębiorstwach jest bariera wiedzy wynikająca ze stopnia skomplikowania kontraktu. Wiedzę o funkcjonowaniu ubezpieczeń można uznać za stosunkowo powszechną, argumentując to chociażby powszechnością ubezpieczeń obowiązkowych posiadaczy pojazdów mechanicznych. Sprawia to, że zasady zawierania ubezpieczeń, zgłaszania szkód czy ustalania składki są znane, również w podmiotach mniejszych. Wiedza o funkcjonowaniu derywatów

${ }^{7}$ Derywaty ubezpieczeniowe dają również pewne korzyści w porównaniu z ubezpieczeniami tradycyjnymi, ale oparte na spekulacji (stąd nie zostają szerzej opisane w niniejszym artykule); dotyczą one m.in. możliwości zabezpieczenia pozycji i opłaty czy braku konieczności posiadania realnego interesu ubezpieczeniowego. 
ubezpieczeniowych ma natomiast charakter specjalistyczny. Efektywne stosowanie tych derywatów w zarządzaniu ryzykiem wymaga korzystania z usług specjalistów, również w zakresie wyceny kontraktów. Co więcej, do tworzenia i wdrażania efektywnych rozwiązań wymagana jest wiedza o funkcjonowaniu obu rynków (ubezpieczeniowego i finansowego), poparta doświadczeniem [Developments... 2000, s. 5].

Warto również pamiętać o pewnych ograniczeniach wynikających z zakresu obowiązujących regulacji prawnych. Czynnikiem negatywnie wpływającym na możliwość szerszego stosowania derywatów ubezpieczeniowych są potencjalne problemy związane $\mathrm{z}$ rozliczaniem takich transakcji w ujęciu księgowym i podatkowym ${ }^{8}$.

\section{Podsumowanie}

Postępujące zjawiska konwergencji rynku finansowego i rynku ubezpieczeń bez wątpienia sprzyjają rozwojowi nowych metod i instrumentów wspierających zarządzanie ryzykiem, również w przedsiębiorstwach. Derywaty ubezpieczeniowe, uznawane za istotny przejaw takiej konwergencji, już obecnie stanowią interesującą alternatywę wobec ubezpieczeń tradycyjnych. Przedstawiony w niniejszym artykule przegląd wybranych cech tych derywatów skłania do sformułowania wniosku, że biorąc pod uwagę rodzaj ryzyka, które można zabezpieczyć, stosując derywaty ubezpieczeniowe, nie ma teoretycznie przeszkód, by znalazły one szersze zastosowanie w zarządzaniu ryzykiem przedsiębiorstw w przyszłości. Najbardziej prawdopodobny wydaje się wzrost zastosowania derywatów pogodowych. Już obecnie wiele przedsiębiorstw (co prawda $\mathrm{z}$ określonych branż) z powodzeniem stosuje te rozwiązania ${ }^{9}$. Zastosowanie derywatów katastroficznych w przedsiębiorstwach z teoretycznego punktu widzenia również jest możliwe. Zważywszy na obserwowaną w ostatnim czasie intensyfikację katastrof naturalnych w regionie europejskim, można przewidywać, że w przyszłości także i te derywaty spotkają się z zainteresowaniem sektora przedsiębiorstw.

Skala ograniczeń w szerszym zastosowaniu derywatów ubezpieczeniowych w przedsiębiorstwach jest jednak istotna. Najpoważniejszym z nich wydaje się bariera wiedzy, szczególnie w gospodarkach o relatywnie mniejszej skali rozwoju rynku finansowego. Stopień skomplikowania konstrukcji derywatów ubezpieczeniowych, wymagający specjalistycznej wiedzy w celu ich efektywnego zastosowania, dla wielu przedsiębiorstw z pewnością stanowi przeszkodę. Jednocześnie

${ }^{8}$ Na problem zwrócili uwagę eksperci Willis [Developments... 2000, s. 6]. Sposób rozliczania kontraktów ubezpieczeniowych w porównaniu z derywatami jest jasno określony.

${ }^{9}$ Wiele przykładów przedstawił J. Preś [2007]. 
brak wiedzy jest czynnikiem podwyższającym koszty transakcyjne derywatów ubezpieczeniowych. Ubezpieczenia tradycyjne wciąż pozostają również bardziej dostępne dla sektora przedsiębiorstw w porównaniu z derywatami ubezpieczeniowymi.

Biorąc pod uwagę skalę ograniczeń zastosowania derywatów ubezpieczeniowych, można przypuszczać, że w przyszłości znaczenie tych derywatów jako substytutów ubezpieczenia tradycyjnego nie będzie wzrastać. Stosowanie derywatów ubezpieczeniowych ma jednak szansę zyskać na znaczeniu w obszarach, w których instrument ten staje się komplementarny wobec innych metod zarządzania ryzykiem, w tym ubezpieczeń tradycyjnych. Sytuacja taka stwarza bowiem impuls do pokonania istniejących barier, w tym tej najpoważniejszej - bariery wiedzy, w obliczu możliwych do osiągnięcia korzyści z lepszego zabezpieczenia ryzyka.

\section{Literatura}

Bank M., Wiesner R. [2010], The Use of Weather Derivatives by Small- and Medium-Sized Enterprises: Reasons and Obstacles, ,Journal of Small Business and Entrepreneurship", vol. 23, nr 4, http://dx.doi.org/10.1080/08276331.2010.10593503.

Banks E. [2004], Alternative Risk Transfer. Integrated Risk Management through Insurance, Reinsurance and the Capital Markets, John Wiley \& Sons, Chichester.

Binkowski P. [2008], Warunki tworzenia i perspektywy rozwoju rynku derywatów pogodowych na rynku krajowym, „Współczesna Ekonomia”, nr 2.

Bouriaux S., MacMinn R. [2009], Securitization of Catastrophe Risk: New Developments in Insurance-linked Securities and Derivatives, „, Journal of Insurance Issues”, vol. 32, nr 1.

Bouriaux M.J., Tomas III [2014], Why Do Insurance-linked Exchange Traded Derivatives Fail? „Journal of Insurance Issues”, vol. 37, nr 1.

Brockett P.L., Wang M., Yang Ch. [2005], Weather Derivatives and Weather Risk Management, ,Risk Management and Insurance Review”, vol. 8, nr 1, http://dx.doi.org/10.1111/ j.1540-6296.2005.00052.x.

Convergence of Insurance and Capital Markets [2008], Working Paper, World Economic Forum, New York.

Cummins J.D., Weiss M.A. [2009], Convergence of Insurance and Financial Markets: Hybrid and Securitized Risk-transfer Solutions, „The Journal of Risk and Insurance”, vol. 76, nr 3, http://dx.doi.org/10.1111/j.1539-6975.2009.01311.x.

Developments in OTC Derivative Instruments, Cat Bonds, Cat-linked Swaps \& New Securitisation Products [2000], ,The Risk Practice”, Willis.

Durbin M. [2011], All about Derivatives, McGraw-Hill, New York.

Frey A., Kirova M., Schmidt C. [2009], The Role of Indices in Transferring Risks to the Capital Markets, Swiss Re, „Sigma”, nr 4, Zurich.

Helfenstein P., Holzheu T. [2006], Securitisation - New Opportunities for Insurers and Investors, Swiss Re, ,Sigma”, nr 7, Zurich.

Hull J.C. [2011], Options, Futures and Other Derivatives, Pearson Education, Harlow. 
Kreczmańska-Gigol K. [2009], Światowy kryzys finansowy a perspektywy rozwoju sekurytyzacji aktywów w Polsce, „Studia i Prace Kolegium Zarządzania i Finansów”, nr 95, Szkoła Główna Handlowa w Warszawie, Warszawa.

Małek A. [2011], Reasekuracja. Klasyczne i alternatywne metody transferu ryzyka ubezpieczeniowego, Poltext, Warszawa.

Preś J. [2007], Zarzq̨dzanie ryzykiem pogodowym, CeDeWu, Warszawa.

Swan E.J. [2000], Building the Global Market. A 4000 Year History of Derivatives, Kluwer Law International, Hague.

Weather Derivatives Market Shows Robust Growth in 2010-2011 [2011], WRMA, http://www.wrma.org/pdf/WRMA2011IndustrySurveypressreleaseFINAL.pdf (data dostępu: 21.03.2014).

Weber Ch. [2011], Insurance Linked Securities. The Role of the Banks, Gabler Verlag, Wiesbaden.

Zailer I. [2004], Derivatives Structures as an Alternative to Traditional Forms of Insurance, „Derivatives Use, Trading \& Regulation”, vol. 10, $\mathrm{nr} 2$.

\section{Insurance Derivatives in Risk Management - An Enterprise Perspective}

Insurance derivatives are instruments that allow insurable risk to be transferred to financial markets. The purpose of the paper is to provide justification for the thesis that insurance derivatives may in the future become an important risk-management tool in enterprises, despite significant currently observable obstacles. The insurance derivatives market is dominated by (re)insurers. However, the convergence of financial and insurance markets may lead to the emergence of new solutions or lead existing solutions into new areas of application. In this context, the paper discusses the role of insurance derivatives and provides a description of their basic types. The paper is based on the conceptual analysis of literature and the method of document analysis in the body of the reports provided by leading international institutions offering insurance derivatives.

Keywords: risk, risk management, derivatives, insurance derivatives, enterprises. 